\title{
レーザーラマン分光装置の製作
}

\author{
藤 山常 毅* ・田隅 三 生* \\ （昭和 45 年 8 月 8 日受理）
}

\section{Laser-Raman Spectrometer}

\author{
Tsunetake Fujiyama and Mitsuo Tasumi \\ Department of Chemistry, University of Tokyo \\ (3-1, Hongo-7, Bunkyo-ku, Tokyo, Japan)
}

Details of the construction of a laser Raman spectrometer and its accessories are described. Raman. spectra observed with the spectrometer are also reported for various chemicals. The instrument includes a He-Ne gas laser source (NEC, GLG-108, $50 \mathrm{~mW}$ ), a Spex 1401 double monochromator, a HTV R-376 photomultiplier (S-20 response), a handmade lock-in amplifier, and a recorder. Using the instrument, excellent spectra are recorded for transparent liquids, various colourless solids, coloured solids (red and yellow), and certain kinds of powder samples. It is ascertained that adjustments of the optical system for the sample beam are essential in obtaining desirable data. All the isotopic Raman bands corresponding to the totally-symmetric stretching vibration of carbon tetrachloride are observed. Temperature dependence of Raman-band intensities is also measured. The result shows that with the instrument the energy difference between rotational isomers can be determined with high accuracy.

\section{1.はじめに}

まずわれわれがレーザーラマン分光計を製作した動機 と目的について触れておきたい. ラマン分光学は 1920 年代に始まる長い歴束をもった分野であるが，レーザー 光の開発によってここ数年間に新たな興味の対象となっ てきている。われわれもレーザーラマン分光に強い関心 を抱いていたが，その長所短所を余すところなく知るた めに装置の製作段階から始めたいと考えた。レーザーの 出現によってはじめてなしうるような研究を目指すには このような基盤の上に立った方が有利であることはいう までもない，またすでに何種かのレーザーラマン分光計 が市販されているが，これらは一般に高佂であり，われ われの目的の一つは不必要な部分をできるだけ省いた単 純な構成で最高の性能号出せるような分光計を比較的安 洒に製作することであった。

われわれのこうした希望を満たすにはある程度まとま った額の研究費が必要であったが，この点に関しては幸 い東レ科学振興助成金を受けることができた（咀和 43

* 東京大学理学部化学教室（東京都文京区本郷 7 丁 目 3 番 1 号)
年度第 9 回助成金, 研究課題「ラマンおよびレイリー散 舌の精度測定とその化学への応用」, 研究代表者東大理 学部島内武彦教授). この機会に東レ科学振興会に深く 感謝する次第である.

過去約一年間にわたってわれわれが行なった装置製作 は一まず成功したと考えられるので，ここでこの過程で 検討した諸問題ををとめて報售することにした，この報 告がこれからレーザーラマン分光に興味を持たれる人々 の参考になればまことに幸いである。

\section{2. 装置の製作}

製作したラマン分光装置全体の概念吕 Fig. 1 に示し た. 測定の目的に応じて図とはやや異なった形をとるこ ともあるが，ほとえどの通常の測定に使用しているもの である、系の構成は, 光源部, 試料部 (照射系および集 光系), 分光系, 検知系, および増幅 (記録) 系からなっ ているが，以下順を追って各部の問題点を記す。

\section{1 光 源 部}

装置の製作にあたって光源の選択は重要であるが，選 択にあたって次の事項を考慮した。

a. 出力の時間安定性が良いもの, 


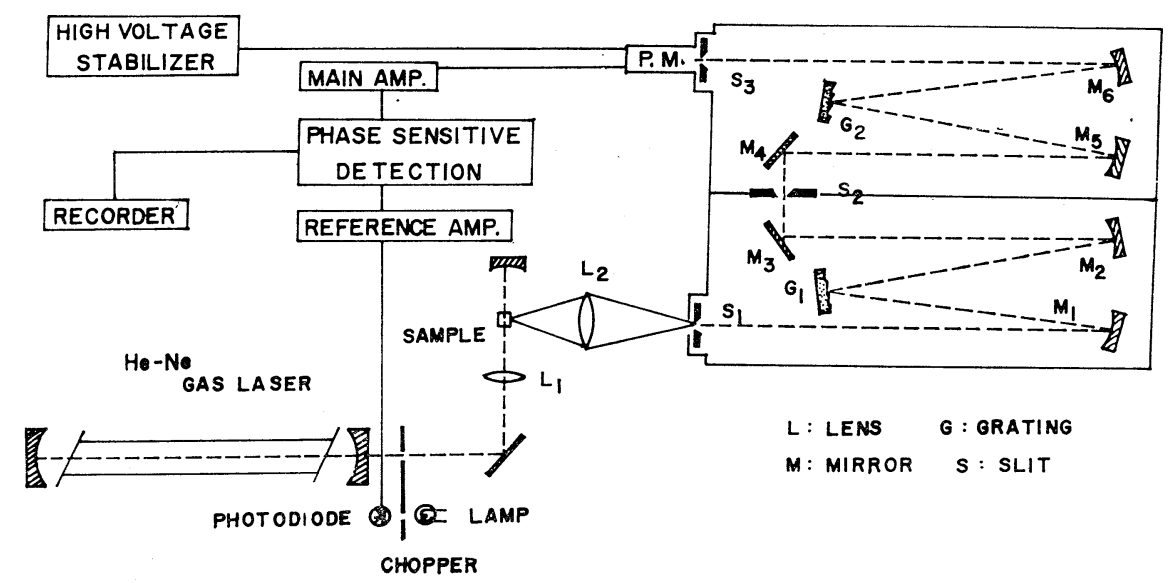

Fig. 1. レーザーラマン分光計の構成. レーザー光源と分光器は同一平面上にはない (本文参照).

b、いろいろの物質のラマン効果の測定に充分なだけ の出方が得られるもの,

c . 定常使用を前提として, 経済性の良いもの,

d。使用法の簡便なもの,

などである. 以上の問題点のうち $\mathrm{c}$ およ゙゙ $\mathrm{d}$ は, 従来の 分光学では，多くの場合問題とならなかったものである が, 高出力レーザー光源の場合, 光源自体が高価である ことはもらろえとして，多数の実験を定常的に消化して ゆく場合の使用電力, 使用水量, レーザー管の交換など に要する諸経費も考慮されるね゙ならない，また一般的に 言って，レーザー光源自体が巨大なものとなるため，装 置全体を目的に応じて組久替えて使用する場合の便宜性 や，実験室内で占める面積なども重要な因子となる。a の時間安定性については，現在市販されているArイオ ンレーザーまたは $\mathrm{He}-\mathrm{Ne}$ 気体レーザーのほとえどが, 充分にラマン散乱の観測用光源として用い得るが, 測定 の目的によっては, 長い時間に生じる出力変動に対して 充分の注意が必要となる. b 汾分光器の性能と関連し て，ぞの程度の性能を持つ装置を作るかによって結論が 大きく変わるものであり, 装置製作上の最大の問題点の 一つである.われわれの場合, 比較的ラマン散乱強度の 弱い分子（たとえば飽和炭化水素）からのラマン線につ いて $5 \mathrm{~cm}^{-1}$ 程度の分解能を得ることを目標とした. 出 力はどの程度のものであれば良いかという問題の解答は 必ずしも一義的ではないが，液体試料の場合，あまり強 い光源で照射すると, 光束に添って試料が沸騰し測定上 好ましくない状況となる. このため, 光源出力は, 約

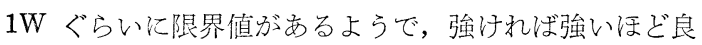
いという結論には至らない. 以上の見地から，Ar イオ ンレーザーおよび $\mathrm{He}-\mathrm{Ne}$ 気体レーザーについて，いろ
いろの出力に対してラマン散乱の観測を行なったのち, 本装置で最終的に選ジれた光源は, 日本電気株式会社製 GIG 108 型 $\mathrm{He}-\mathrm{Ne}$ 気体レーザー（出力は約 $50 \mathrm{~mW}$, シングルモード）である.この光源は，レーザー発振用 の電源部を含主が，全体の使用にあたって，電圧変動 $5 \%$ 以下の $100 \mathrm{~V}$ の入力電源を必要とするため, 定電圧 装置として，山水社製のコンタック MS 1000 (1 KVA) 定使用している。

$\mathrm{He}-\mathrm{Ne}$ 気体レーザーの発振波長は $6328 \AA$ (赤色) で, ラマン散乱観測のもずかしかった着色物質でも, 赤ない し黄色の試料のラマン散乱の測定には支障ない. $\mathrm{He}-\mathrm{Ne}$ レーザーでは, Ar イオンレーザーほどの高出力が得ら れないが，発振波長がずっと長波長であるため，後に記 す光電増倍管の感度を考慮にいれてもなお, 到達分解能 は高出力 Ar イオンレーザーを使用した場合と大差な い。なお，緑ないし青色の物質に対しては，He-Ne レ ーザーは著しく不利な光源となる。

光源出力との関係で, 室温の恒常性は重要である. 一 般的に言って, $\mathrm{He}-\mathrm{Ne}$ 気体レーザーで高出力字得るた めには長い発振管を必要とし，これの伸び縮みによる出 力变動は無視しえない大きさとなる，したがって，レー ザー出力は, 室温の変化に伴い鋭敏に変化する.上記レ ーザー管の場合, 実験室温度は, 測定時 $\pm 1^{\circ} \mathrm{C}$ 程度にお さえれば問題がないことが確認される。

\section{2 試 料 部}

定常的に使用している試料部は, 液体試料および結晶 試料のラマン散乱の測定に適した光学系で, 主として $90^{\circ}$ 方向の散乱光を観測するものである.

光源から水平方向に出た平面鏡で垂直方向には水上げ られ，焦点距離 $10 \mathrm{~cm}$ の凸レンズ $\left(\mathrm{L}_{1}\right)$ で試料を照射す 
る. この際の光の焦点中心は試料の上下方向の中間点任 合致している. 試料定通り抜けた光は, 再び曲率半径 $10 \mathrm{~cm}$ の凹面鏡または試料セル上部に置かれた小平面鏡 で反射され，ふたたび試料を照射する。この際，試料を 上下に通過するレーザー光の光束は厳密化一致すること が望ましい，試料からの散乱光は，焦点距離 $4 \mathrm{~cm}$ の凸 レンズ $\left(\mathrm{L}_{2}\right)$ で集光され, 分光器の入ロスリット $\left(\mathrm{S}_{1}\right)$ 上 に像它結ぶ. 試料と分光器スリットの距離壮 $20 \mathrm{~cm}$ で, スリットの結像は拡大形になるように凹レンズ $\left(\mathrm{L}_{2}\right)$ 置 いている.この部分の光学系の構成は，複合レンズを用 いたり，分光器とは反対側代散乱した光を而鏡で集光 したりして集光效率を上げるとか，照射光定試料セル内 で多重反射させて散乱效率を上げるなどの工夫がいるい ろ試みられているが，本装置では，最も単純な系で充分 良いスペクトルの観測它行なうこと它目標としている。 この段階での光学調整ははな快だ微妙であり, 測定結果 の良否を左右することが多く, 試料部の光学系は, 測定 に用いる試料の状態によって，その都度調整する必要が ある。この意味から言っても, 集光のための光学系法,

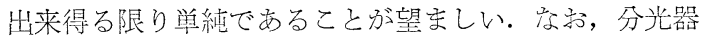
の口径やスリット幅を考慮した效率の良い集光系につい

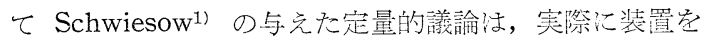
作る際の助け汭なる。

液体試料の測定に用いるラマンセルとしては, 石英安 た注ガラス製のものを用いている。セル材質の均一性 やセル材質面の平面度は重要で, 出来得る限り垥一で平 らな面をとうして散乱光它集め视ばならない, 本装置で は, 光学的に平らに久がいた石英板を熔融して張り合わ せた直方体の七ルを用いている $(1 \times 1 \times 1.5 \mathrm{~cm}$, 試料入 口はすり合わせコック)、円筒状のセルは，特殊な細工

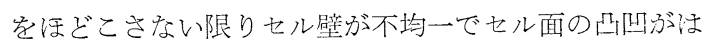
げしくなりやすい，宋た，試料管自体が凸レンズになる ため，集光系の調整が不便になりやすい，同様沈，みが かれていない結晶試料表面の凸凹四や，液体セル面の污れ は，しばしば測定結果に致命的悪影響を与える，以上で 触れなかった特殊な測定での試料セルについて结後述す る.

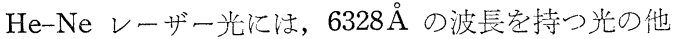
に, 強度は弱いがこれとは波長の異なる多くの自然放出 線が混っている，乙れを除去するために，試料系と光源 との間の距離を充分に長くとり，また，レーザ一光束は 3 個のダイアフラム（光束が通過するのに充分な径を持 つ穴をあけた板）を通過した後試料を照射するようにし

1) R. I. Schwiesow: J. Opt. Soc. Am. 59, 1285 (1969)
た。これはレーザー光が強い指向性を有するのに反し て，自然放出線は方向性を持たないことを利用するもの である。この方法によって，ほとんどの測定は，自然放 出線の妨害なしに行なわ和るが，後に述べる粉末試料 や，特に弱いラマン散乱の観測には, $6328 \AA$ に透過極大 を持つ干渉フィルターを用いる必要がある。

\section{3 分 光 系}

分光器の選択に際して留意したととは，
a。分散が良い
b．迷光が少ない
c。明るい
d. 波長駆動，スリット等の機械系が安定している などである。a と c とは, 散乱断面樻の大きいレイリー 散乱の妨害の少ない条件下で, 散乱断面積の小さいラマ ン散乱光を観测するため生じる要求で, 互い纪矛盾す るものであるが共に重要である. 各種市販分光器のう 台，上記の要求を満足するものとして，Spex 社製 1401 型ダブルモノクロメータ一を使用した．光学系は,

Tandem Czerny-Turner 型で, $102 \times 102 \mathrm{~mm}$ の回折格 子 (1200本 $/ \mathrm{mm}$, ブレーズ波長 $5000 \AA) 2$ 枚を用いてお り, コリメータ一鏡の焦点距離は $75 \mathrm{~cm}, \mathrm{~F} 6.8$, 逆分散

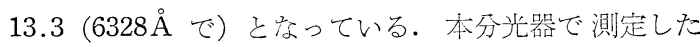
$3131 \AA$ 附近の水銀線ダブレットを Fig. 2 亿示した. 測 定は二次の回折を用いた．乙の分光器は，本装置の目指 す性能を得る流分なものであり，字た，目的行応じて， 全く同等の光学系から成る 2 台のシングルモノクロメー ターとして使用しうることや，光電測光と写真測光（こ の場合はシングルで用いる）のいずれ定も用いられる等 の利点を備えている. 本分光器の持つ偏光特性について は後述する、な抄，一般的にダブルモノクロメーターの 光学調整は微妙であり, 実験室の床や分光器台の振動を

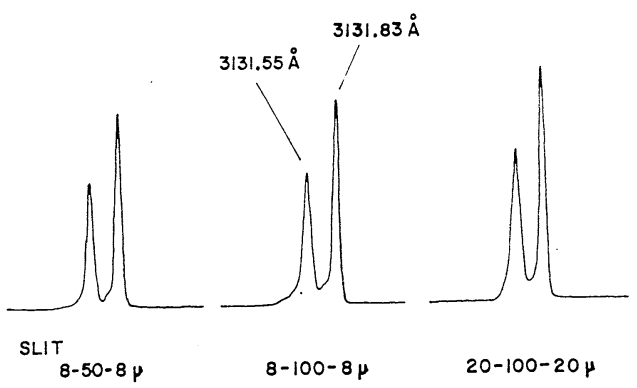

Fig. 2. Spex 1401 型分光器によって測定した $3131 \AA$ 附近の水銀線ダブレット。スリット幅は 図に示してあるように左から $s_{1}=8 \mu, s_{2}=50 \mu$, $s_{3}=8 \mu ; s_{1}=8 \mu, s_{2}=100 \mu, s_{3}=8 \mu ; s_{1}=20 \mu$, $s_{2}=100 \mu, s_{3}=20 \mu$ であり, スリットの高さはい ずれも $2 \mathrm{~mm}$ で測定した。 \&たスキャン速度は $25 \mathrm{~cm}^{-1} / \mathrm{min}$ ，チャート速度は $180 \mathrm{~mm} / \mathrm{min}$ であ る. $\left(s_{1}, s_{2}, s_{3}\right.$ については Fig. 1 参照). 


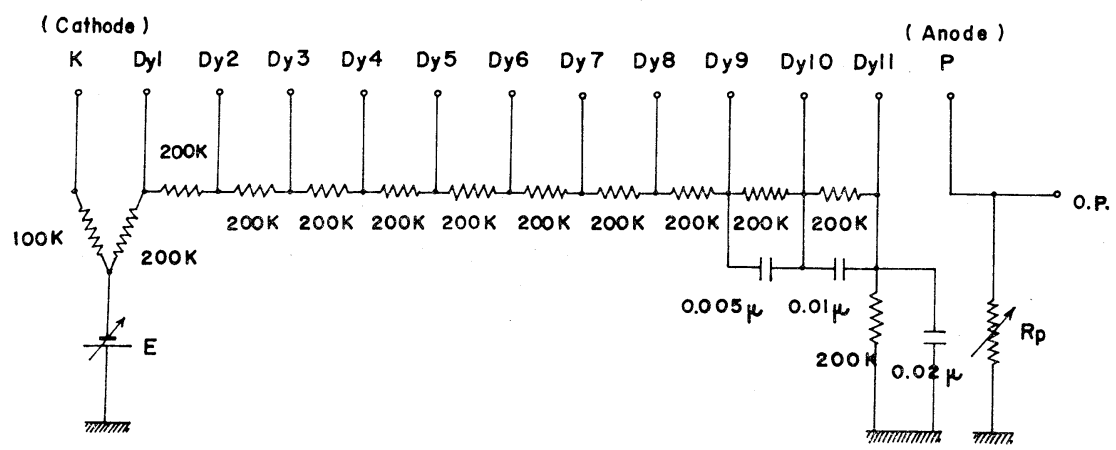

Fig. 3. 光電子增倍管 (HTV R-376) の端子間配線.

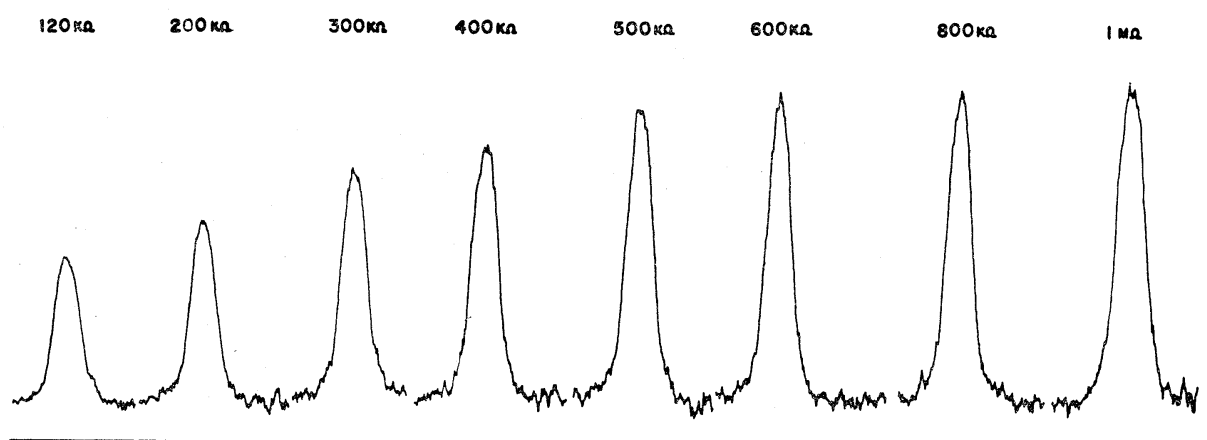

Fig. 4. $R_{p}$ の大きさと光電子増倍管の出力の関係. $n$-ペンタンの $400 \mathrm{~cm}^{-1}$ のラマン線金用いて測定.

\section{最少限におさえることが大切である.}

\section{4 検 知 系}

光電測光の検知器として光電子増倍管を用いている が，いろいろの増倍管を使用した結果，S-20 型の応答 のものならぼ，電気系に位相敏感検波方式を用いる限 りほぼ同様の結果を得ている，使用した増倍管は， HTV R-374, HTV ZA-005 (以上浜松テレビ), RCA 7326 等であるが，最終的には，廉洒でしかも性能の良 いHTV R-376 省使用している. Fig. 3 は増倍管端子 間の配線を示したもので, 全体として全電圧調整形感応 制御方式を構成しており, 加印電圧は一 $-900 \mathrm{~V} て ゙$ 最良の $S / N$ 比が得られる. $R_{p}$ の值は, 増倍管出力を变元る. Fig. 4 は, 特定のラマン線を同一条件で, いろいろの $R_{p}$ の值に対して観測した結果を示した。本装置では, 通常 $600 \mathrm{k} \Omega$ で使用している. 增倍管用直流定電圧電源として は, 応用電気研究所製 OHT-3 型安定電流電源を用い た. 本機の出力は直流 $0.1 \sim 3 \mathrm{kV}$ 加変, 最大出力電流 $4 \mathrm{~mA}$, ドリフト $0.05 \%$ 以下である.

増倍管は, ほとえどの場合室温で使用して充分に満足 すべき結果を得ている. 本装置では, 増倍管受光面を冷 却使用することもできるが，増幅系に光子計数方式を採
用する場合以外は，使用法が煩雑なわりに利が少ない。

\section{5 増幅 (記録) 系}

増幅系には, 直流増幅方式, 位相敏感検波方式, およ び光電子計数方式2)の三者についての製作，検討を行な った結果, 本装置の目的とする性能を満足するために は, 製作が容易で安価な位相敏感検波方式が最適である と考元られる. 最終的に本装置に用いられている増幅系 の回路を Fig. 5〜Fig. 9 に示した.

Fig. 5 は増幅系の定電圧回路, Fig. 6, Fig. 7 は, そ れぞれ主信号および参照信号の増幅回路である. 参照信 号については Fig. 8 に示すごとく, $6.3 \mathrm{~V}$ 用豆ランプ を光源として，ブォトトランジスター OS 14 で参照增 幅系への入力を作っている，信号および参照信号は，ヒ ステリシスモーターにとりつけられた回転板によって $375 \mathrm{~Hz}$ の交流信号にチヨップされる. 用いたヒステリ シスモーターは, 日本サーボ社製 HM 8 型ヒステリシ スモーターで, 回転数は 1500 r.p.m. であり，回転板は 15 個の羽根のついたボール紙製のものである. 参照光 源に用いる電源は, 時間安定性の良い, GS バッテリー

2) S. A. Miller: Rev. Sci. Instrum. 39, 1923 (1968) を参照した。 
$5 R K 16$

GRA3

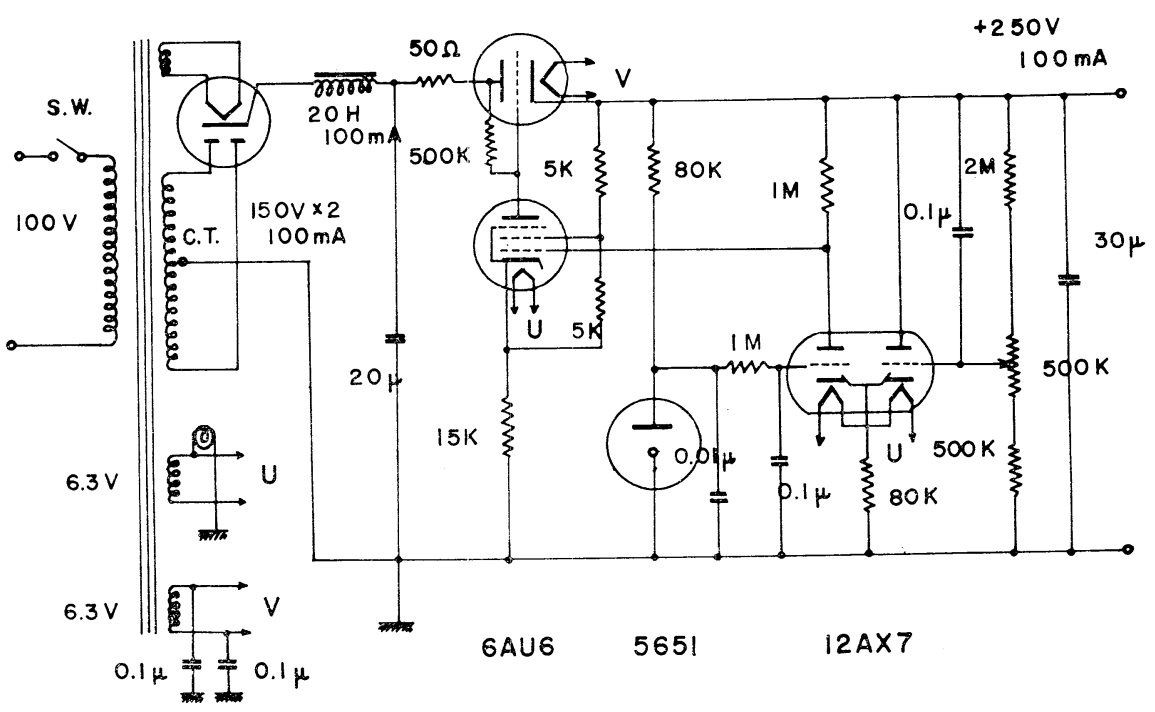

Fig. 5. 增幅系用定電压回路。

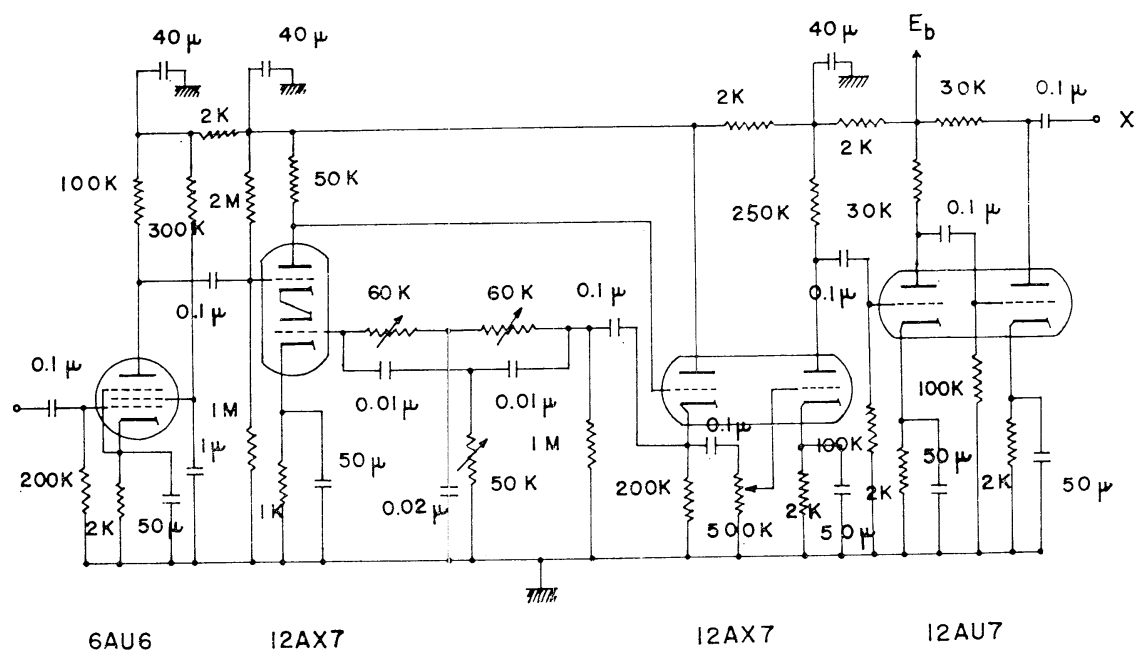

Fig. 6. 主信号用增幅回路.

社製 GS 6V 96 AHPS 型蓞電池学用いている。信号側 增幅回路は，Fig. 6 に示すように $375 \mathrm{~Hz}$ に極大を持つ フィルターとしてのトイン $\mathrm{T}$ 型回路を内蔵している. 配線にあたって特に导ずかしい点はないが，信号の通り 路のシールドを完全にし，八厶冠最小限にすることが朋 要である. 本装置では, 初段の五㮌管用ヒーター電源の みは, 别に直流安定電源炎用いている。参照側回路は,

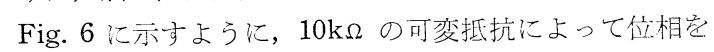
変えられるように設計した。この部分は，いわゆる移相
回路（フェーズシフター）といわれるもので，この回路 で位相を変えると波形がかなり乱れるが，最終結果には 影響がない。主信号と参照信号の位相は, チヨッパーの 位置を変えることによって機械的に合わせた後, 参照国 路の移相回路で微調整するようにしている. 増幅された 主信号および参照信号は，それぞれ，Fig. 9 の位相敏感 検波回路の $X$ および $Y$ に入り，主信号は， $375 \mathrm{~Hz}$ の 夕選択的に検波される. 最終段は積分回路で, 時定数は 多極スイッチの切り智えによって变えられる. Fig. 9 回 
路の $20 \mathrm{k} \Omega$ の可変抵抗は，検波回路のバランスを变える ことを目的としたものである．検波後の信号をさらに電 力増幅することも試夕たが, 一般的には, 市販のレコー

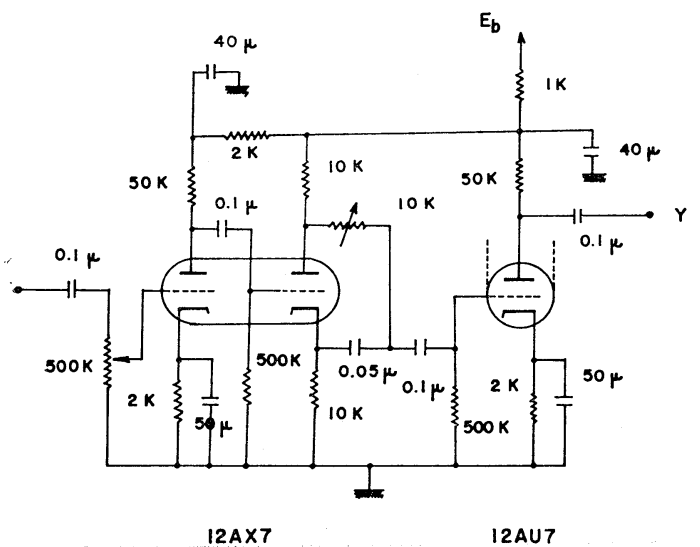

Fig. 7. 参照信号用增幅回路.

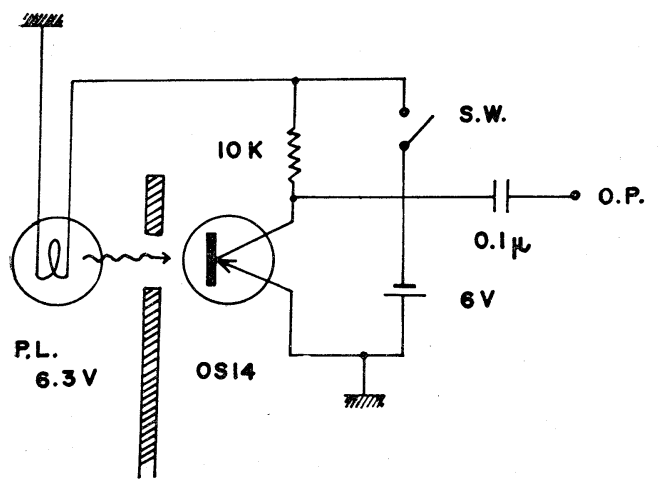

CHOPPER

Fig. 8. 参照信号発生回路.
ダー感度が著しく良くなっているので無用の努力であっ た. 積分後の出力は, 横河電機社製 3046 型レコーダー に記録される.このレコーダーの場合, マーカー用ペン がついているが, 波長駆動部に羽根のついた回転板を取 り付け，回転板の両側に取り付けた豆ランプとフォトダ イオードからなる系から出力を得, これによってリレー 㟈閉することによってマーカ一用ペンを駆動した。マ ーカーの間隔は $10 \mathrm{~cm}^{-1}$ とした.

以上で装置についての問題点に触れたが, 測定室の設 計についても留意すべきことがある. 光源の安定性, 光 学系の安定性を考えると, 床のしっかりした部屋が望ま しく，また室温は $\pm 1^{\circ} \mathrm{C}$ 程度に恒温であることが望まし い. 散乱現象の観測に一般的な問題としては, 実駼室の ホコリにも充分に気を配るととが大切である.

\section{3. ラマン散乱の測定}

ラマン分光装置の性能の評価は必ずしも一義的ではな く, 装置自体の有する性能に加えて, 試料の種類や試料 の調整の仕方による結果の良否が大きな評価の因子とな ってくる. ここでは, 総合的に性能を評価するに適した いくつかの実測例它示々う。

\section{1 液体試料}

ラマン分光装置の製作者が性能テストの標準として用 いる, 四塩化炭素 $\mathrm{CCl}_{4}$ の $460 \mathrm{~cm}^{-1}$ バンドについての 実測結果を Fig. 10 に示した. 自然状態での塩素には二 つの同位体である $\mathrm{Cl}^{35}$ 和よび $\mathrm{Cl}^{37}$ があるため, $\mathrm{CCl}_{4}$ は, $\mathrm{CCl}_{4}{ }^{35}, \mathrm{CCl}_{3}{ }^{35} \mathrm{Cl}^{37}, \mathrm{CCl}_{2}{ }^{35} \mathrm{Cl}_{2}{ }^{37}, \mathrm{CCl}^{35} \mathrm{Cl}_{3}{ }^{37}$, および $\mathrm{CCl}_{4}{ }^{37}$ の五つの同位体分子が，31.6:42.2:21.1:4.7:0.4 の比率で存在する.これら五つの同位体分子からのラマ ン散乱が $460 \mathrm{~cm}^{-1}$ 附近で $2 \sim 3 \mathrm{~cm}^{-1}$ の間隔で観測され るはずである。事実 Fig. 10 では 5 本のラマン線が分離

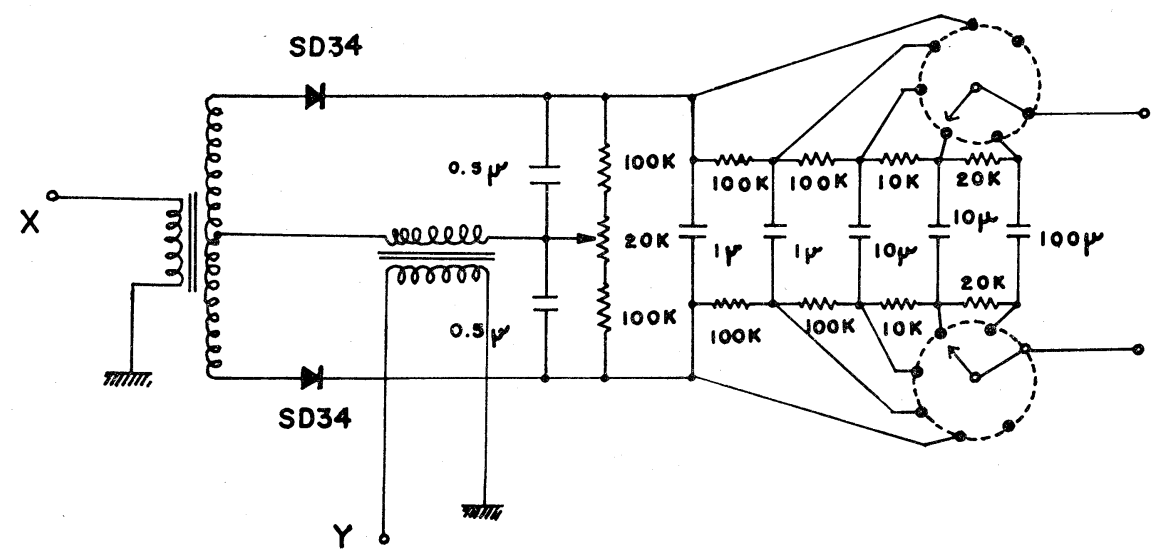

Fig. 9. 位相敏感検波回路. $X$ に主信号, $Y$ に参照信号を入れる. 


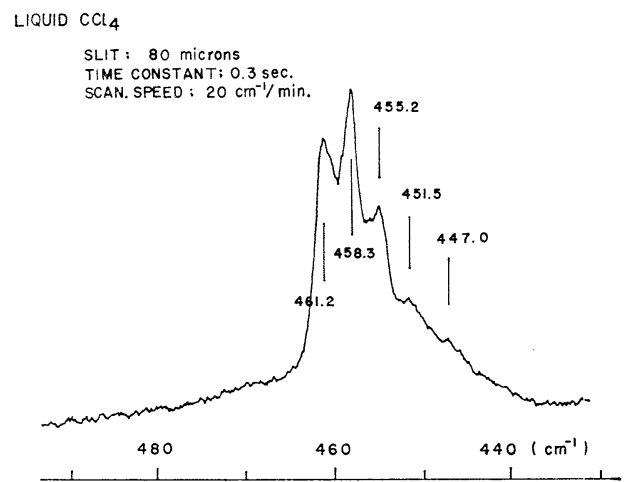

Fig. 10. 四塭化炭素の $460 \mathrm{~cm}^{-1}$ 附近のラマン゙線, 塩素の同位体による多重線が見られる(本交参照). スリット幅 $80 \mu$, 高さ $1 \mathrm{~cm}$, 時定数 $0.3 \mathrm{sec}$, スキャン速度 $20 \mathrm{~cm}^{-1} / \mathrm{min}$.

観測されているが，このうち少なくとも高波数側の 3 本 は, 存在率の高い $\mathrm{CCl}_{4}{ }^{35}, \mathrm{CCl}_{3}{ }^{35} \mathrm{Cl}^{37}$, および $\mathrm{CCl}_{2}{ }^{35} \mathrm{Cl}_{2}{ }^{37}$ によることは間違いない ${ }^{3)}$. 測定条件は，スリット幅

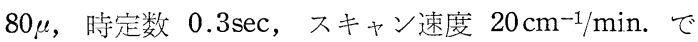

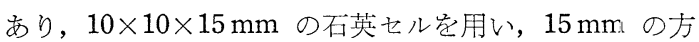
向をスリット方向に合わせている. この結果は, 光学 系, 電気系を極度に簡単にした本装置で, きわめて高い 性能が出ていることを端的に示している.

液体試料について留意すべきは試料の精製であって, 明らかに螢光物質の混入している場合などはもちろんの こと, 細かい気泡やコロイドの存在は，多くの場合測定 結果に致命的悪影響穵及ぼす. 水溶液, 特に無機物質や 高分子化合物の水溶液については, 試料の作製自体が重 要かつもずかしい仕事となることを指摘したい。

\section{2 固体試料および着色物質}

無色透明の単結晶試料については無色透明の液体の測 定と同様である.

前述のごとく $\mathrm{He}-\mathrm{Ne} レ$ レ゙ーの場合波長が $6328 \AA$ の赤色光であるので, 緑ないし青色の物質以外はほとえ ど問題なく取り扱うことができる. Fig. 11, 12, 13 に黄 色および赤褐色固体のラマン散乱の実測結果を示す。W ずれの場合も $90^{\circ}$ 方向の散乱を測定したものであるが， レイリー線から $20 \mathrm{~cm}^{-1}$ 以上の領域は容易に測定できる ことがわかる．結晶試料の測定で重要なととは入射光の 通る所や散乱光のとり出し面が平たえ均一でなければな らないことである. 結晶中に不均一な部分がある場合, 乱反射された入射光が直接分光器に飛び込んで著しくラ

3) G. Herzberg: Infrared and Raman Spectra of Polyatomic Molecules (D. Van Nostrand Co., 1945)
マン散乱の測定を导ずかしくする。

細かい結晶や粉体試料のラマン散乱の観測は上に述べ たような理由で多くの場合困難である。粉末試料の一例

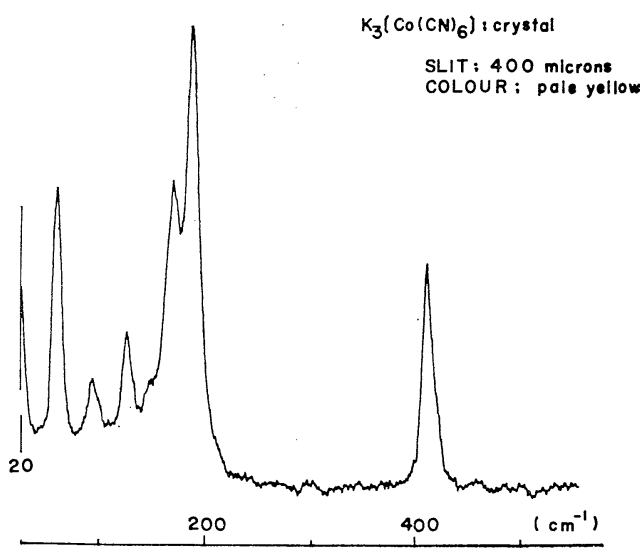

Fig. 11. $\mathrm{K}_{3}\left[\mathrm{Co}(\mathrm{CN})_{6}\right]$ 結晶 (淡黄色) のラマンスぺ クトル。 スリット幅 $400 \mu$ ，スリットの高さ $1 \mathrm{~cm}$.

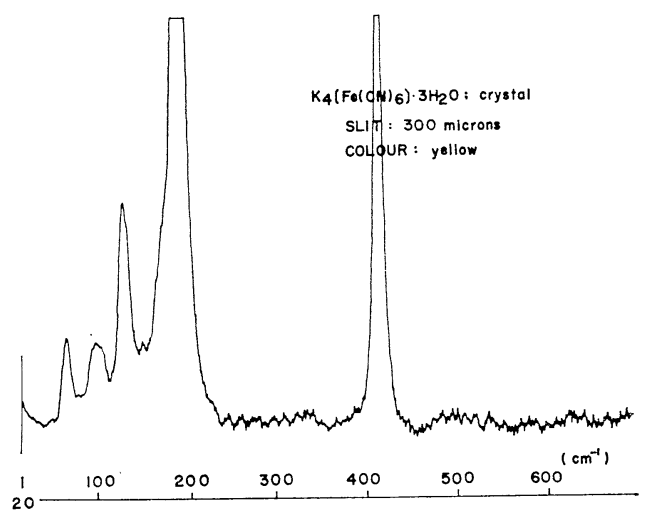

Fig. 12. $\mathrm{K}_{4}\left[\mathrm{Fe}(\mathrm{CN})_{6}\right] \cdot 3 \mathrm{H}_{2} \mathrm{O}$ 結晶 (黄色) のラマ ンスペクトル. スリット幅 $300 \mu$, 高さ $1 \mathrm{~cm}$.

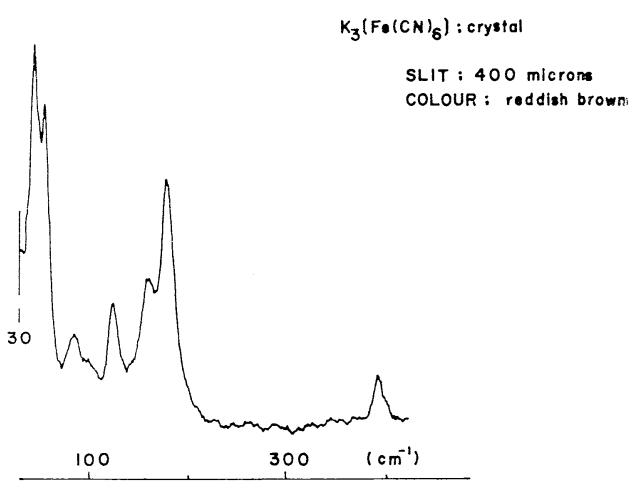

Fig. 13. $\mathrm{K}_{3}\left[\mathrm{Fe}(\mathrm{CN})_{6}\right]$ 結晶（赤褐色）のラマンス. ペクトル. スリット幅 $400 \mu$, 高さ $1 \mathrm{~cm}$. 


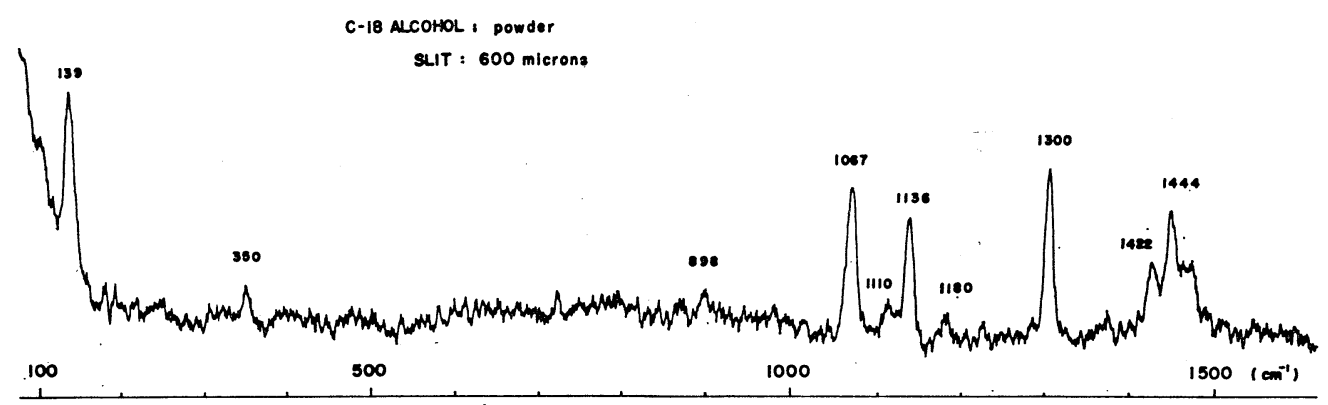

Fig. 14. ステアリルアルコール $\left(\mathrm{C}_{18} \mathrm{H}_{37} \mathrm{OH}\right)$ 錠戍のラマンスペクトル. スリット幅 $600 \mu$, 高さ $1 \mathrm{~cm}$.

としてステアリルアルコール $\mathrm{C}_{18} \mathrm{H}_{37} \mathrm{OH}$ についての測定 例を Fig. 14 に示した. 試料は赤外吸収測定用臭化カリ 錠剂整型器を用いて錠剂様に整型したものである. 錠剂 の側面に小さな穴をあけレーザー光をそれに入射させる 方法とレーザー光を錠剤表面に当てる（錠剤をやや傾け て）方法を試みたが, この場合はほぼ同じ結果を得た。

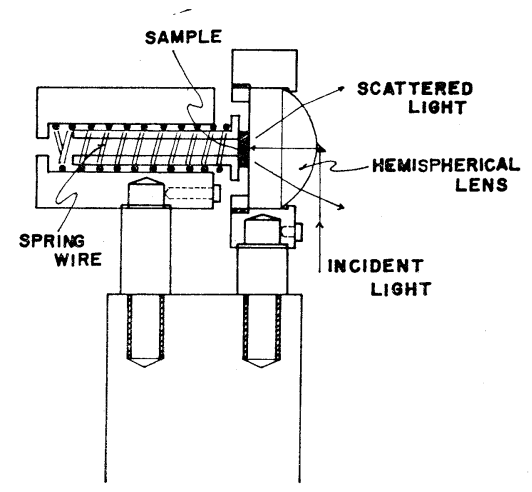

Fig. 15. 半球形レンズと直角プリズムを用いた後 方散乱測定のための光学系.

Fig. 15 により一般的に粉体試料のラマン散乱測定に用 いるために製作した光学系を示す。これは Cary 社製の ものからヒントを得てわれわれが設計したものである. 光学系は半球形のレンズとその先端につけられた直角プ リズムが主要な部分である。垂直に上がってきたレーザ 一光は直角プリズムで水平方向に曲げられ, 半球形レン

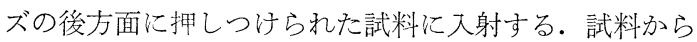
のラマン散乱光は半球形レンズで集光されたのち適当な 光学系によって分光器入射スリット上に集められる. こ の場合の観測は本質的に後方散乱でレイリ一散乱の断 面積の小さな方向での観測となっていることがこの方法 の利点の一つとなるが，それ以外飞も粉体の試料面があ る程度平たえになることや方向の乱れたラマン散乱光を 巧みに集光するという利点を備えている.

\section{4. 強度の関係する測定}

從来の水銀灯を用いるラマン分光器に対してレーザー を光源とするラマン分光器がまさる点は，自記記録が容 易になったこと抢よび方向性を含めて測定結果の再現性 が良くなったことの 2 点にあるといえる. この結果従来 のラマン分光器に比較して，スペクトル強度の関係した 測定の問題点のいくつかが解決されたと考光られる。い うまでもなく絶対強度の測定については本質的にむずか しい問題が残るが，相対強度の測定は充分可能でありか つ意義あるものである．これによってある種の定量的な 研究が可能になる. 振動スペクトルの見地に立って考え れば，ラマン分光法には吸収スペクトル法で問題となる スリット函数や異常分散などの問題がなく, 強度を扱う 際には吸収法より有利であると考它られる。比偏光 ラマンスペクトル，高温および低温での測定の実例を示 しつつ, スペクトルの縦軸の実験的問題に触れる.

\section{1 装置の直線性}

入力に対して出力が直線的関係にあるかどうかは光電 増倍管, 増幅器および位相敏感検波器によって決められ る. Fig. 16 は HTV-ZA 005 光電子増倍管について測定 された $6328 \AA$ の光の量と増倍管出力との関係它した もので, この場合は出力 $15 \mu \mathrm{A}$ 程度が直線性の限界を与 えている. 位相敏感検波の直線性は参照側出力の大きさ が信号側出力に比較して充分大きければ良く, われわれ の装置では参照側出力を $50 \mathrm{~V}$ 一定で使用している. 装 置全体としての直線性を調べるためには入射光量を变え て最終出力をみる必要があり, この目的には中性フィル ターが有用である. Kenko filter ND 2, 4, 8 (それぞれ 光量をもとの約 $1 / 2,1 / 4,1 / 8$ にするもの) を用いて 1 , 2-ジブロムエタンの $\mathrm{CBr}$ 伸縮によるラマン带強度を測 定したが，この結果装置全体が良好な直線性をもってい ることを確認した。

\section{2 偏光スペクトルおよび偏光解消度}




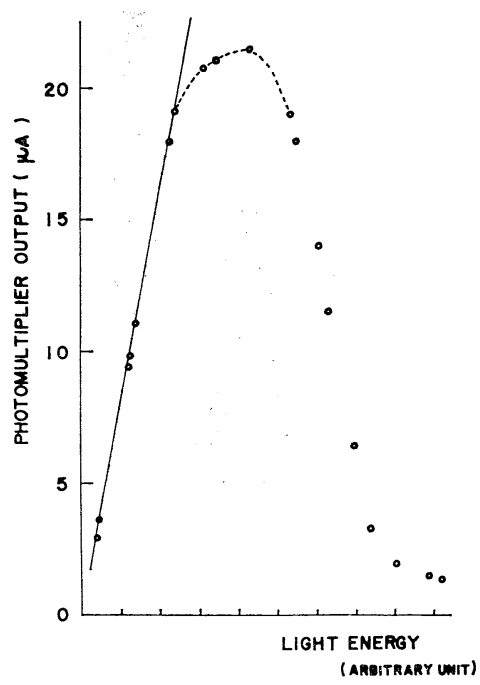

Fig. 16. $6328 \AA$ の光の強さと光電子增倍管

(HTV-ZA 005) の出力の関係.

相対強度に関係した測定のう台偏光大ペクトルおよび 偏光解消度の測定はレーザーラマン分光法が徉来のもの に比べて有利となる一例である.

偏光測定の際問題となるのは分光器の偏光特性, 㴜光 子の不完全性および透過率である. 一般的にいって, 完 全に同等な偏光子が 2 個あれぼ上記の三つの量を実験的 に決定することができる.われわれは次のようにしてこ れらの值を沈定した．ここで用いる記号をまず定義して おく.

$I_{0}$ : 入射光の強さ.

$I \|^{\circ}, I_{\perp}^{\circ}: I_{0}$ のスリットに平行および垂直の㴜光成分 の強さをとれぞれ $I \|^{\circ}, I_{\perp}^{\circ}$ とする。

$t$ : ポーラロイド板 (偏光子) の透過率.

$\alpha$ : ポーラロイド板の偏光の不完全性.

$\beta_{\|}$：スリットに対して平行な偏光の分光器に対する透 過率.

$\beta_{\perp}$ ：スリットに対して垂直な偏光の分光器に対する透 過率.

$\gamma: \beta_{\perp} / \beta \|$.

（i）ポーラロイド1枚を使用する場合 ポーラロ イドの偏光方向をスリットに平行および垂直とすると き，実測される光の強さは次のように表わされそ.

$$
\begin{aligned}
& I_{\|} \mathrm{obs}=t I_{\|}{ }^{\circ} \beta_{\|}+t \alpha I_{\perp}^{\circ} \beta_{\perp} \\
& I_{\perp} \text { obs }=t \alpha I^{\circ} \| \beta_{\|}+t I_{\perp}^{\circ} \beta_{\perp}
\end{aligned}
$$

（ii）ポーラロイド2枚を使用する場合２枚のポ ーラロイドの1枚をスリットに平行, 他方を垂直におく 場合と 2 枚ともスリットに垂直にする場合とで実測され
る光の強さは次のようになる。

$$
\begin{aligned}
& I_{\perp \|} \text { obs }=t^{2}\left(\alpha I\left\|^{\circ} \beta\right\|+\alpha I_{\perp}^{\circ} \beta_{\perp}\right) \\
& I_{\perp \perp} \text { obs }=t^{2}\left(\alpha^{2} I_{\|}{ }^{\circ} \beta \|+I_{\perp}^{\circ} \beta_{\perp}\right)
\end{aligned}
$$

(iii) Wま求めたいのは $t, \alpha$ および $\gamma$ であるが， $\alpha$ およびッは次式で与えられる。

$$
\begin{aligned}
& \alpha=\frac{(1-u+v+u v) \pm \sqrt{(1-u+v+u v)^{2}-4 u^{2}}}{2 u} \\
& \gamma=\frac{u-\alpha}{1-u \alpha}
\end{aligned}
$$

ここで

$$
u=\frac{I_{\perp} \mathrm{obs}}{I_{\|\|^{\mathrm{obs}}}}=\frac{\alpha+\gamma}{1+\alpha \gamma}, \quad v=\frac{I_{\perp \perp} \mathrm{obs}}{I_{\perp \|} \mathrm{obs}}=\frac{\alpha^{2}+\gamma}{\alpha+\alpha \gamma}
$$

である。

$\alpha$ とケが求められたらポーラロイドを便用するときと しないときの $I$ obs の比から $t$ 唯求められる.

上のようにして得られた $t, \alpha$ および $\gamma$ を Fig. 17 に 示した。われわれぶ用いたポーラロイド板は古いもので 㐫りり良い性能のものではない。も乙非常に性能の良い 偏光子 $(t \fallingdotseq 1, \alpha \fallingdotseq 0)$ を用いれば， 1 個の偏光子だけで $\gamma$ を決定することが可能なはずである.

本装置では入射光の偏光方向は半波長板（(Spex 社よ り購入）によって任意に回転できるようこし，散乱光の 偏光方向はポーラロイドで解析するようにした．偏光解 消度についてはおよそ二桁の精度は確実に出せるが，強 いラマン光については三桁も可能である.これについて は別に報告する予定である。
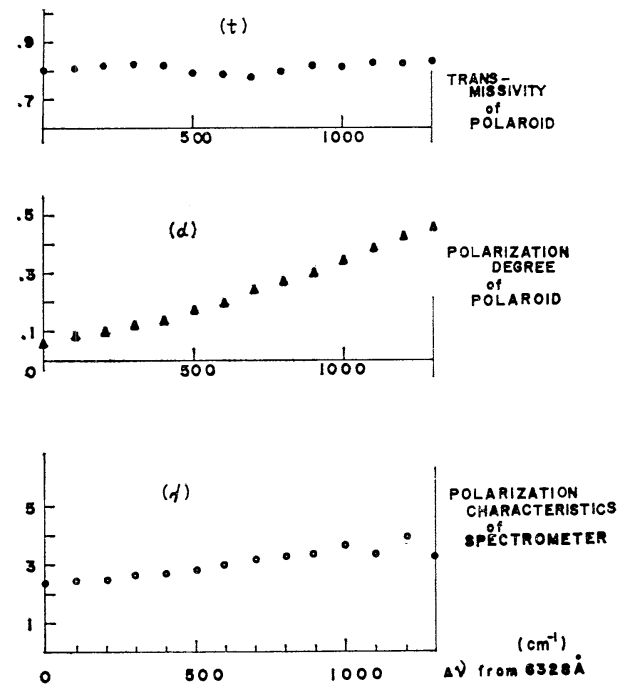

Fig. 17. ポーラロイド板の透過率 $(t)$, 偏光の不完 全性 $(\alpha)$, および Spex 1401 型分光器の偏光特 性 $(\gamma)$. 

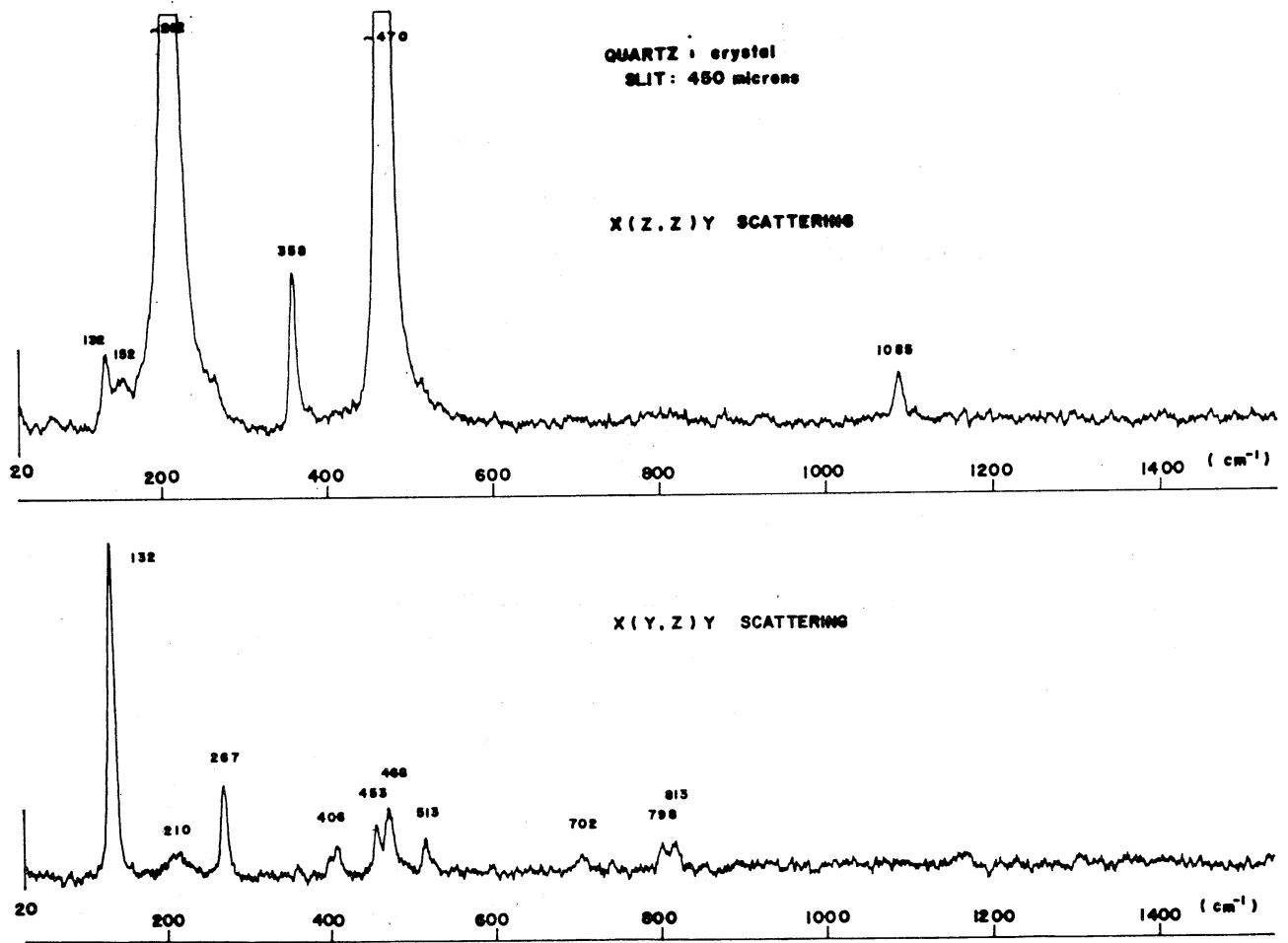

Fig. 18. $\alpha$-石英結晶の偏光ラマンスペクトル.

偏光スペクトルの測定例を Fig. 18 に示す. 測定に用 いた $\alpha$-石英は一軸結晶であるから全体で六通りの偏光 スペクトルが観測されるが，このうち $X(Z, Z) Y$ およ び $X(Y, Z) Y^{*}$ で表わされる測定結果を示す.ただし $Z$ 軸を結晶軸の方向と定義した.

\section{3 低温高温スペクトル}

相対強度の測定が可能になると二つ以上の物質の存在 比を定量的に調べる目的にラマンスペクトルを用いるこ とができる. 共存する分子種が熱平衡にある場合には， 室温のみでなく高温および低温でのラマン散乱の観測が 重要となる。

Fig. 19 に本装置用の低温セルの一例定示す．全体は 入射光および散乱光の通る密面をもつデュワー瓶からな る、空はできるだけ平らな方がよい。試料はガラス管に 封入し泠媒に直接浸される，この方法は液体，固体のい ずれであっても共通に用いることができる（常温気体の もの安液化させて測定することも可能). Fig. 20 では泠 媒としてドライアイスーエタノールを用い，いろいろの

* $A(B, C) D$ で $A$ は入射光の進行方向, $B$ はその 偏光方向, $C$ 注散乱光の偏光方向, $D$ はその進行 方向である.
温度でラマンスペクトルを観測する場合の一例を示して いる．右側にあるガラス管およびデュワー瓶にはエタノ ールが入って和り，ガラス管中にドライアイスを細かく 砕いたものを適量加えることによって試料を任意の温度 に保つものである.この方法によって試料を希望の温度

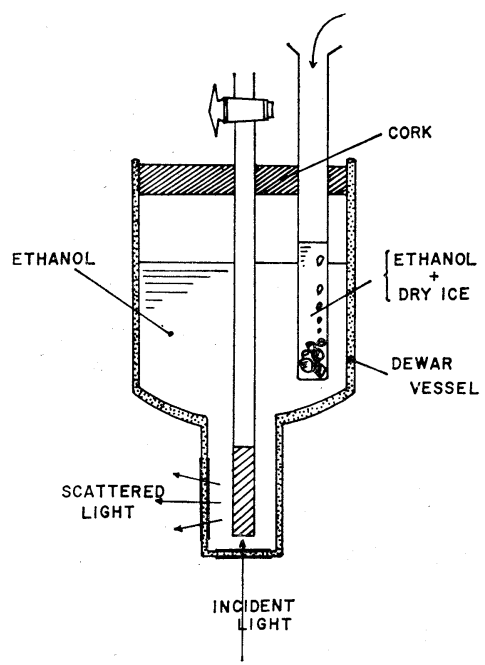

Fig. 19. レーザーラマン分光用の低温セルの一例. 


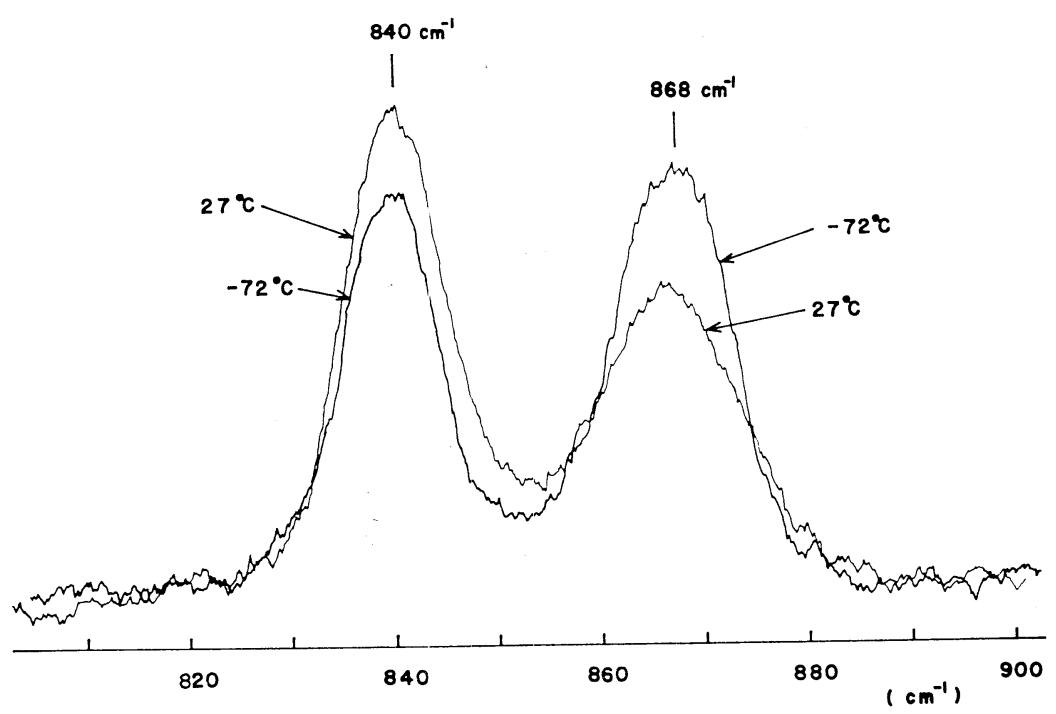

Fig. 20. n-ペンタン液体のラマンスペクトルの温度変化.

$840 \mathrm{~cm}^{-1}$ は TG 形, $868 \mathrm{~cm}^{-1}$ は TT 形の線である.

を中心として $\pm 1^{\circ} \mathrm{C}$ の範囲に設定することは容易であ る. Fig. 20 は測定の一例で用いられた試料は $n$ ヘペンタ ソである. $840 \mathrm{~cm}^{-1}$ のラマン線は回転異性体のうち TG 形に，また $868 \mathrm{~cm}^{-1}$ のラマン線は TT 形によるもので

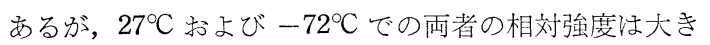
く変化していることがわかる。

Fig. 21 に高温セルの構成を示す. 用いた材質は主と してパイロフェライトで, 電気絶縁と保温性が良くまた

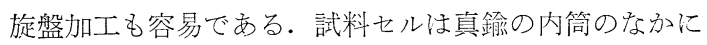
大れるが，これは試料部の温度を均一にするために重要

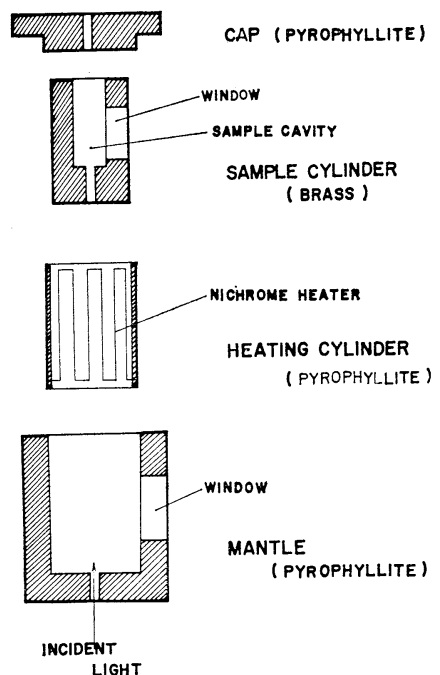

Fig. 21. レーザーラマン分光用高温セルの一例.
である．温度はニクロム線に通す電流を変えることによ って制御し，室温から $300^{\circ} \mathrm{C}$ の範囲ではきわめて一定の 温度を得ることができる. Fig. 22 は 1,2-ジブロムエタ ン $\left(\mathrm{BrCH}_{2} \mathrm{CH}_{2} \mathrm{Br}\right)$ の $\mathrm{CBr}$ 伸縮振動についての測定結果 を示すが, 回転異性体の $\mathrm{T}$ 形 $\left(660 \mathrm{~cm}^{-1}\right)$ および $\mathrm{G}$ 形 $\left(583 \mathrm{~cm}^{-1}\right)$ に対応するラマン線の相対強度の变化が明ら かである。

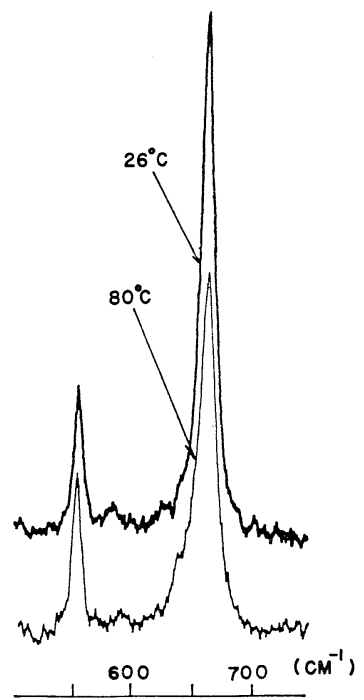

Fig. 22. 1，2-ジブロムエタン液体のラマンス ペクトルの温度変化. 高波数側 $\left(660 \mathrm{~cm}^{-1}\right)$ は トランス形, 低波数側 $\left(583 \mathrm{~cm}^{-1}\right)$ はゴーシュ 形の線である。 
ここで強調しておきたいことは, 吸収スペクトル法で は精密な温度変化の実験がすずかしいが，これに比較し てラマン分光法では高精度のデータがかなり容易に得ら れるという点である.

\section{5. おわりに}

以上でわれわれの製作した装置について重要と考える 点について記したが, 実際にラマン分光学の研究を進め るに際して，たと光ば波長較正，スリット幅の較正，偏 光解消度を含さラマン強度の測定なぞの重要な問題が残 っている，李た論交全体の長さを考光て，各項目につい
て多くの興味ある結果を記し残した。これらの問題につ いては，別に報告してゆきたいと考えている．本報文の 結論としていえることは, 従来の水銀灯を光源とする マン分光装置に比べて，レーザーを光源とするものの製 作が容易であること, ならびに, 実際にレーザーラマン 分光装置を製作する際の問題点についてこれまでに主張 されてきたことの多くが，必ずしも正しくないというこ とである.

おわりに, 本研究を進めるに当たって, 東京大学理学 部島内研究室の全員なかんずく酒井純修士の協力があっ たことを附記し感謝の意を表したい。 